\title{
Hypocholesterolemic Effect of Biscuit Made from Purple Sweet Potato Flour, Starch, and Fiber Rich Flour on Rats
}

\author{
Oktavianna Ginting ${ }^{1}$, Elisa Julianti ${ }^{1 *}$, Rona J. Nainggolan ${ }^{1}$ \\ ${ }^{1}$ Department of Food Science and Technology, Faculty of Agriculture, Universitas Sumatera Utara, Medan, 20155, \\ Indonesia \\ * Corresponding Author: elisal@usu.ac.id
}

\begin{abstract}
The solid residue from purple sweet potato (PSP) starch has a high enough dietary fiber and can be processed into fiber rich flour. In this study, biscuits were made from flour, starch and fiber rich flour from PSP in a ratio of 75: 5: 20. The resulting biscuits were then tested for their hypocholesterolemic effect in rats. 30 male rats were randomly subdivided into 6 (six) groups. Group 1, 2, 3 (healthy rats) were given a basal diet, and basal diets containing 25\% and 50\% of PSP biscuit respectively. Group 4, 5, and 6 (hypercholesterolemic rats) were given basal diets containing $25 \%$ and $50 \%$ of PSP biscuits, and gemfibrozil $21.6 \mathrm{mg} / 200 \mathrm{~g}$ rat body weight respectively. After 14 days, the total cholesterol, triglyceride, low density lipoprotein (LDL), and high density lipoprotein (HDL) of blood serum were recorded. The results showed that the administration of 50\% PSP biscuits of the basal diet for 14 days had a hypocholesterolemic effect both on healthy and hypercholesterolemic rats. In the healthy rats, the difference in the dose of PSP biscuits had no effect $(\mathrm{p}>0.05)$ on HDL, but in hypercholesterolemia rats, the dose of biscuits had a different effect $(\mathrm{p}<0.05)$ on total cholesterol, triglycerides, LDL and HDL.
\end{abstract}

Keywords: purple sweet potato, anthocyanin, hypocholesterolemic effect, biscuit, food security

\section{INTRODUCTION}

Purple sweet potato consumption is an effort to develop alternative food that can maintain food security in some developing countries. Purple sweet potato can also be processed into various products which have some added value [1] and also one of functional foods due to the nutritional composition and also has physiological function for health, as well as an attractive appearance and taste [2].

High cholesterol is one of the causes of cardiovascular disease [3]. The accumulation of fat on the wall of the blood vessel will cause the narrowing of the circulation so that blood flow will be reduced. Cholesterol plaque on the blood vessel is fragile and easily breaks, causing a wound on the arteries. Blood vessel walls that caused blood to clot. As a result blood clots will block the blood vessels [4].

Changes in physical activity, diet and lifestyle affect the biological conditions in the body and cause problems in nutrition that cause overweight and obesity [5]. Nutritional problems in the body have an impact on increasing the risk of heart disease, stroke, diabetes mellitus type 2, and hypercholesterolemic. The components of hypercholesterolemic include total cholesterol, triglycerides, HDL and LDL levels, and its prevalence is increasing in both developed and developing countries [6].

Anthocyanins in purple sweet potato acts as an antioxidant that is able to lower the risk of hypercholesterolemic and prevent oxidative stress [7]. Anthocyanins in purple sweet potato show activity as free radical scavenger antimutagenic, and reduce blood pressure [8]. The anthocyanin content in purple sweet potato gives the purple color which is spread from the skin to the flesh of the tuber [9]. Anthocyanin in PSP has a function such as antioxidant, anticancer, antibacterial, and gives protection from the ravage of liver, heart and stroke [10]. 
Intake of foods rich in fiber such as purple sweet potato can reduce the risk of increasing blood glucose and total cholesterol levels. The lower consumption of fiber, means higher cholesterol levels [11]. The substitution of wheat flour in biscuits into purple sweet potato is an innovation that develops local food, the anthocyanins in purple sweet potato acts as pigments that increase the appearance of the color of biscuits [12]. The purpose of this study was to evaluate the hypocholesterolemic effect of biscuits made from purple sweet potato flour, starch, and fiber rich flour on rats.

\section{METHODOLOGY}

\subsection{Materials}

Purple sweet potato as the main ingredient with similar harvest age and size (12-18 cm long and 200-300 grams in weight), were obtained from West Phak Phak farmers. The ingredients for making biscuits were sugar, shortening, baking powder and salt. The chemical used in flour making is sodium metabisulfite,

The tools used in the flour, starch, and fiber making are knife, bucket, hammer mill, filter cloth, drying oven, sieve shaker, 60 and 80 mesh sieves. Biscuit making using equipment such as mixers and toaster oven. The hypocholesterolemic effect testing using a lancet, strip, tube, spuit and autocheck multi-monitoring system.

\subsection{Preparation of Biscuit}

The biscuits were prepared by using procedure Seprina [13] with modification as on Table 1 below. Dried ingredients such as flour, baking powder, and salt mixed using a mixer with low speed. Shortening and sugar mixed until forms a cream using a mixer. Then the dried dough is put into the cream dough and mixed using a mixer until a smooth dough is formed.

The resulting dough is formed into sheets using a roller with a thickness of $3 \mathrm{~mm}$ then molded into a circle with a diameter of $4 \mathrm{~cm}$, and placed on a baking pan that has been lined with baking paper, baked in an oven preheated to $165^{\circ} \mathrm{C}$ for 20 minutes. Then biscuits were cooled for 30 minutes at room temperature and packed in polyethylene plastic.

\subsection{Hypocholesterolemic Effect Testing in Vivo}

The test uses male wistar rats (Rattus norvegicus) measuring 150-200 grams. Total of 30 rats were divided into 6 groups, namely:

$\mathrm{A}_{1}=$ healthy rats were given basal diet (negative control).

$\mathrm{A}_{2}=$ healthy rats were given basal diets containing $25 \%$ PSP biscuits.
$\mathrm{A}_{3}=$ healthy rats were given basal diets containing $50 \%$ PSP biscuits.

$\mathrm{A}_{4}=$ hypercholesterolemic rats were given basal diets containing $25 \%$ PSP biscuits.

$\mathrm{A}_{5}=$ hypercholesterolemic rats were given basal diets containing 50\% PSP biscuits.

$\mathrm{A}_{6}=$ hypercholesterolemic rats were given gemfibrozil $21.6 \mathrm{mg} / 200 \mathrm{~g}$ rat body weight (positive control).

Rats were acclimatized for a week. Then the hypercholesterolemic rat group will be given high fat foods to increase cholesterol level, such as propylthiouracil $0.01 \%$ and $2 \mathrm{ml}$ quail egg yolk/day for 35 days. The rats were fasted before having their blood taken to test the cholesterol level as pretest data. Then the rats would be given each treatment for 14 days, then they would be fasted to take the blood for the post test data.

The way of taking rat blood is by pricking the tail using a lancet, the blood that comes out is analyzed for blood lipid profiles including total cholesterol using CHOD-PAP method, triglycerides using GPO-PAP method, HDL using CHOD-PAP method, and LDL using [14]. As well as weighing the weight and rats daily feed consumption remains.

Hypocholesterolemic effect testing of biscuit from PSP flour, starch and fiber from solid waste of starch processing in vivo on healthy and hypercholesterol rats. The research data analysis used was Kruskall Wallis on percentage reduction of total cholesterol, triglyceride, LDL level; percentage increase of HDL level and percentage of body weight changes. And normality test Shapiro Wilk test on daily feed consumption.

\section{RESULT AND DISCUSSION}

In this study, rats were fed with quail egg yolk and thiouracil to induce an increase in cholesterol levels in the rat blood. Quail egg yolk contains $2138.17 \mathrm{mg} / 100 \mathrm{~g}$ and $35.5 \%$ fat [15]. Administration of propylthiouracil can increase cholesterol levels endogenously by reducing thyroid hormone synthesis. Propyl Tio Uracil is a chemical substance that inhibits the action of thyroid hormone in the form of tablets dissolved in water and administered to test animals [16]. The hypercholesterolemic rats were used to study the potential of hypocholesterolemic effect of supplementation of biscuits from sweet potato flour, starch and fiber rich flour. Biscuits were given daily with feed and feeding was carried out ad libitum. Rats were fed 36 grams/day based on observations of the rats' daily consumption amount. The level of feed consumption is influenced by the energy needs according to activity level or movement of the rats in stable [17]. The daily consumption feed of rats was shown in Table 2. 
Table 1 Formulation in biscuit making

\begin{tabular}{ll}
\hline Ingredient & Amount $(\mathrm{g})$ \\
\hline PSP flour & 75 \\
PSP starch & 5 \\
PSP fiber & 20 \\
Sugar & 15 \\
Shortening & 40 \\
Baking powder & 1.5 \\
Salt & 0.4 \\
\hline
\end{tabular}

Table 2 Daily consumption feed on rats

\begin{tabular}{lll}
\hline Treatment & Feed amount $(\mathrm{g})$ & Feed remain $(\mathrm{g})$ \\
\hline $\mathrm{A}_{1}$ & $25.53 \pm 0.65$ & 10.47 \\
$\mathrm{~A}_{2}$ & $23.04 \pm 0.63$ & 13.00 \\
$\mathrm{~A}_{3}$ & $22.03 \pm 0.29$ & 13.97 \\
$\mathrm{~A}_{4}$ & $22.95 \pm 0.24$ & 13.05 \\
$\mathrm{~A}_{5}$ & $24.58 \pm 0.79$ & 11.42 \\
$\mathrm{~A}_{6}$ & $25.15 \pm 0.77$ & 10.85 \\
\hline
\end{tabular}

Value represents of five replicates data \pm standard deviation

Table 3 Total cholesterol on rats

\begin{tabular}{lccc}
\hline Treatment & \multicolumn{2}{c}{ Total cholesterol blood serum (mg/dL) } & \multicolumn{2}{c}{$\begin{array}{l}\text { Percentage reduction of total cholesterol } \\
\text { levels }(\%)\end{array}$} \\
\cline { 2 - 3 } & Pretest & Posttest & $7.63 \pm 1.38$ \\
\hline $\mathrm{A}_{1}$ & $58.40 \pm 7.09$ & $54.00 \pm 7.11$ & $14.18 \pm 1.33$ \\
$\mathrm{~A}_{2}$ & $48.80 \pm 8.53$ & $41.80 \pm 6.69$ & $30.99 \pm 1.02$ \\
$\mathrm{~A}_{3}$ & $53.60 \pm 5.81$ & $37.00 \pm 4.12$ & $24.40 \pm 0.86$ \\
$\mathrm{~A}_{4}$ & $109.20 \pm 15.52$ & $82.60 \pm 12.22$ & $49.26 \pm 1.62$ \\
$\mathrm{~A}_{5}$ & $116.60 \pm 10.53$ & $59.20 \pm 6.14$ & $16.25 \pm 3.89$ \\
$\mathrm{~A}_{6}$ & $94.00 \pm 12.47$ & $78.80 \pm 11.78$ & \\
\hline
\end{tabular}

Value represents of five replicates data \pm standard deviation

Table 4 Triglyceride levels on rats

\begin{tabular}{llll}
\hline Treatment & \multicolumn{2}{l}{ Triglyceride levels $(\mathrm{mg} / \mathrm{dL})$} & $\begin{array}{l}\text { Percentage reduction of triglyceride } \\
\text { levels }(\%)\end{array}$ \\
\cline { 2 - 4 } & Pretest & Posttest & $13.25 \pm 0.69$ \\
$\mathrm{~A}_{1}$ & $96.00 \pm 34.95$ & $83.40 \pm 30.53$ & $32.72 \pm 2.77$ \\
$\mathrm{~A}_{2}$ & $87.40 \pm 10.81$ & $58.80 \pm 7.50$ & $35.56 \pm 3.29$ \\
$\mathrm{~A}_{3}$ & $70.40 \pm 19.73$ & $45.80 \pm 14.69$ & $31.28 \pm 6.49$ \\
$\mathrm{~A}_{4}$ & $168.00 \pm 49.93$ & $115.20 \pm 33.30$ & $66.21 \pm 13.89$ \\
$\mathrm{~A}_{5}$ & $175.20 \pm 38.98$ & $58.20 \pm 25.11$ & $23.59 \pm 2.80$ \\
$\mathrm{~A}_{6}$ & $155.20 \pm 24.98$ & $118.40 \pm 18.19$ &
\end{tabular}

Value represents of five replicates data \pm standard deviation

Table 5 HDL levels on rats

\begin{tabular}{llll}
\hline Treatment & \multicolumn{2}{l}{ HDL level $(\mathrm{mg} / \mathrm{dL})$} & $\begin{array}{l}\text { Percentage increase in HDL levels } \\
(\%)\end{array}$ \\
\cline { 2 - 3 } & Pretest & Posttest & $10.44 \pm 1.28$ \\
$\mathrm{~A}_{1}$ & $19.40 \pm 2.51$ & $21.40 \pm 2.51$ & $13.97 \pm 3.40$ \\
$\mathrm{~A}_{2}$ & $18.80 \pm 4.66$ & $21.40 \pm 5.32$ & $15.41 \pm 1.39$ \\
$\mathrm{~A}_{3}$ & $20.80 \pm 2.39$ & $24.00 \pm 2.74$ & $10.74 \pm 2.93$ \\
$\mathrm{~A}_{4}$ & $20.80 \pm 2.05$ & $23.00 \pm 1.87$ & $63.08 \pm 3.43$ \\
$\mathrm{~A}_{5}$ & $25.20 \pm 4.44$ & $41.00 \pm 6.67$ & $13.25 \pm 3.34$ \\
$\mathrm{~A}_{6}$ & $17.60 \pm 3.58$ & $20.00 \pm 4.42$ & \\
\hline
\end{tabular}

Value represents of five replicates data \pm standard deviation

Table 6 LDL levels on rats

\begin{tabular}{lccl}
\hline Treatment & \multicolumn{2}{l}{ LDL levels $(\mathrm{mg} / \mathrm{dL})$} & \multicolumn{2}{l}{$\begin{array}{l}\text { Percentage reduction of LDL levels } \\
(\%)\end{array}$} \\
\cline { 2 - 3 } & Pretest & Posttest & \\
\hline $\mathrm{A}_{1}$ & $19.80 \pm 9.69$ & $15.92 \pm 8.10$ & $23.23 \pm 9.93$ \\
$\mathrm{~A}_{2}$ & $12.52 \pm 5.76$ & $8.64 \pm 4.03$ & $30.09 \pm 8.31$ \\
$\mathrm{~A}_{3}$ & $18.72 \pm 7.19$ & $3.84 \pm 5.20$ & $85.40 \pm 20.05$ \\
$\mathrm{~A}_{4}$ & $54.80 \pm 7.65$ & $36.56 \pm 6.84$ & $33.55 \pm 4.86$
\end{tabular}




\begin{tabular}{cccc}
$\mathrm{A}_{5}$ & $56.36 \pm 10.94$ & $6.56 \pm 4.54$ & $89.00 \pm 5.95$ \\
$\mathrm{~A}_{6}$ & $45.36 \pm 12.39$ & $35.12 \pm 9.96$ & $21.75 \pm 9.81$ \\
\hline
\end{tabular}

Value represents of five replicates data \pm standard deviation

Table 7 Body weight on rats

\begin{tabular}{lccc}
\hline Treatment & \multicolumn{2}{l}{ Body weight $(\mathrm{g})$} & \multicolumn{2}{c}{ Percentage of body weight changes (\%) } \\
\cline { 2 - 3 } & Pre test & \multicolumn{1}{l}{ Post test } & \\
\hline $\mathrm{A}_{1}$ & $165.40 \pm 14.19$ & $178.40 \pm 15.57$ & $7.85 \pm 0.25$ \\
$\mathrm{~A}_{2}$ & $189.00 \pm 30.06$ & $194.40 \pm 30.95$ & $2.90 \pm 0.41$ \\
$\mathrm{~A}_{3}$ & $190.33 \pm 26.22$ & $197.00 \pm 29.39$ & $2.40 \pm 0.37$ \\
$\mathrm{~A}_{4}$ & $176.20 \pm 31.10$ & $189.20 \pm 28.69$ & $4.23 \pm 0.40$ \\
$\mathrm{~A}_{5}$ & $189.00 \pm 38.69$ & $196.80 \pm 43.25$ & $5.85 \pm 0.53$ \\
$\mathrm{~A}_{6}$ & $177.25 \pm 17.06$ & $182.00 \pm 15.81$ & $3.77 \pm 0.42$ \\
\hline
\end{tabular}

Value represents of five replicates data \pm standard deviation

Blood cholesterol, triglyceride, HDL, LDL levels, and body weight of rats after feeding high cholesterol and thiouracil (pretest), as well as after supplementation of biscuits from flour, starch and fiber-rich flour from purple sweet potato (posttest) can be seen in Table 3, Table 4, Table 5, Table 6, and Table 7

\subsection{Reduction of Total Cholesterol Blood Serum}

Table 8 Reduction of total cholesterol blood serum on healthy rats

\begin{tabular}{ccc}
\hline Treatment & $\begin{array}{c}\text { Percentage reduction of total } \\
\text { cholesterol levels }(\%)\end{array}$ & Mean rank \\
\hline $\mathrm{A}_{1}$ & $7.63 \pm 1.38$ & 3.00 \\
$\mathrm{~A}_{2}$ & $14.18 \pm 1.33$ & 8.00 \\
$\mathrm{~A}_{3}$ & $30.99 \pm 1.02$ & 13.00 \\
\hline
\end{tabular}

Value represents of five replicates data \pm standard deviation

Table 8 shows the significant $(\mathrm{p}<0.05)$ decrease of total cholesterol levels on healthy rats from the highest to lowest was $A_{3}, A_{2}$, and $A_{1}$. In group $A_{1}$, we were only given a basal diet for 14 days so the decrease in total cholesterol levels was slower. In group $\mathrm{A}_{3}$, the effect of decreasing total cholesterol levels was more significant than group $\mathrm{A}_{2}$. This was due to the higher consumption of PSP biscuits. The anthocyanins and dietary fiber content in PSP biscuits contributed to the decrease in total cholesterol levels on healthy rats. Anthocyanin extract is able to reduce total cholesterol levels in the blood through a mechanism that inhibits the activity of HMG CoA reductase so that cholesterol synthesis in the liver will be inhibited [18]. The inhibition of the HMG CoA reductase enzyme on cholesterol synthesis is the inhibition of the HMG CoA reductase enzyme which catalyzes the conversion of HMG CoA to mevalonic acid which is the initial step of cholesterol synthesis [19].

Table 9 Reduction of total cholesterol blood serum on hypercholesterolemic rats

\begin{tabular}{|c|c|}
\hline Treatment & $\begin{array}{l}\text { Percentage reductic } \\
\text { cholesterol levels }\end{array}$ \\
\hline $\mathrm{A}_{4}$ & $24.40 \pm 0.86$ \\
\hline $\mathrm{A}_{5}$ & $49.26 \pm 1.62$ \\
\hline $\mathrm{A}_{6}$ & $16.25 \pm 3.89$ \\
\hline
\end{tabular}

Value represents of five replicates data \pm standard deviation

Table 9 shows the significant $(\mathrm{p}<0.05)$ reduction of total cholesterol on hypercholesterolemic rats from the highest to lowest was $A_{5}, A_{4}$ and $A_{6}$. In group $A_{5}$, the effect of lowering total cholesterol level was higher than group $\mathrm{A}_{4}$. This is due to the higher consumption of PSP biscuits, the anthocyanins and dietary fiber on PSP biscuits could reduce total cholesterol levels on hypercholesterolemic rats.

The effect given by anthocyanins is by inhibiting the action of HMG-CoA Reductase enzyme so that the cholesterol synthesis will be inhibited [18]. Dietary fiber have a rple in binding bile acids, bile acid are synthesized by cholesterol in the liver to help decompose fatty acids, red $y$ gefo 2 avaitability of bile acids will cause cholesterol taken from the blood to liver for additional bile acids synthesis, so that the total cholesterol levels will be reduced [5].

Group $\mathrm{A}_{6}$ were treated with gemfibrozil $\mathrm{mg} / 200 \mathrm{~g}$ rat body weight, causing a decrease in total cholesterol level (16.25\%). This was because consumption of gemfibrozil can suppress the amount of total cholesterol by suppressing intracellular cholesterol storage by inhibiting the action of ACAT (Acyl-CoA Carboxylase Acyl Transferase) enzyme and causing reduction to cholesterol esters.

\subsection{Reduction of Triglyceride levels}

Table 10 Reduction of triglyceride levels on healthy rats

\begin{tabular}{|c|c|c|c|}
\hline Treatment & $\begin{array}{l}\text { Percentage } \\
\text { reduction of } \\
\text { triglyceride } \\
\text { levels }(\%)\end{array}$ & Mean rank & $\mathrm{p}$ \\
\hline $\mathrm{A}_{1}$ & $13.25 \pm 0.69$ & 3.00 & 0.005 \\
\hline $\mathrm{A}_{2}$ & $32.72 \pm 2.77$ & 9.00 & \\
\hline $\mathrm{A}_{3}$ & $35.56 \pm 3.29$ & 12.00 & \\
\hline \multicolumn{4}{|c|}{ Value represents of five replicates data \pm standard deviation } \\
\hline \multicolumn{4}{|c|}{$\mathrm{p}$} \\
\hline \multicolumn{4}{|c|}{$\begin{array}{l}\text { Table } 10 \text { shows the significant }(\mathrm{p}<0.05) \text { reduction in } \\
\text { dydedode levels on healthy rats from the highest to }\end{array}$} \\
\hline
\end{tabular}


healthy rats, because they were only given a basal diet for 14 days. In group $A_{3}$, the effect of decreasing the triglyceride levels was more significant than $A_{2}$. This shows that the consumption of anthocyanins in PSP biscuits can cause reduction in triglyceride levels.

Table 11 Reduction of triglyceride levels on hypercholesterolemic rats

\begin{tabular}{cccc}
\hline Treatment & $\begin{array}{c}\text { Percentage reduction of } \\
\text { triglyceride levels }(\%)\end{array}$ & Mean rank & $\mathrm{p}$ \\
\hline $\mathrm{A}_{4}$ & $31.28 \pm 6.49$ & 7.60 & 0.003 \\
$\mathrm{~A}_{5}$ & $66.21 \pm 13.89$ & 13.00 & \\
$\mathrm{~A}_{6}$ & $23.59 \pm 2.80$ & 3.40 &
\end{tabular}

Value represents of five replicates data \pm standard deviation

Table 11 shows that the significant reduction of triglyceride levels from the highest to lowest was $\mathrm{A}_{5}, \mathrm{~A}_{4}$, and $A_{6}$. group $A_{5}$ had a significant effect on reduction of triglyceride level than $\mathrm{A}_{4}$. This shows that anthocyanins in PSP biscuits contributed to reduction of triglyceride levels on hypercholesterolemic rats.

The mechanism of anthocyanins in reducing triglyceride levels is activating AMPK (Adenosine Monophosphate Protein Kinase) which can inhibit the action of HMG-CoA Reductase enzyme in cholesterol synthesis, and also inhibit the action of ACC (Acetyl CoA Carboxylase) enzyme so that it will increase fatty acid oxidation and reduce fatty acid synthesis [20]. In addition, antioxidants in PSP biscuits can also increase lipoprotein lipase enzymes which have a role in breaking down the triglyceride [21].

Whereas group $\mathrm{A}_{6}$, rats were given gemfibrozil 21,6 $\mathrm{mg} / \mathrm{g}$ rat body weight showed a decrease in triglyceride levels by increasing lipolysis of lipoprotein triglyceride through binding of lipoprotein lipase with PPAR $\alpha$ (Peroxisome Proliferator Activated Receptor alpha). The metabolism of triglyceride is regulated by enzyme lipoprotein lipase, which can be inhibited by APO C III. Consumption of gemfibrozil can also suppress the amount of APO C III [22].

The result of the breakdown of triglyceride by lipoprotein lipase was free fatty acid and chylomicron remnants [23]. The free fatty acid can be synthesized back into energy reserves or stored as triglyceride in adipose tissue. Chylomicrons remnants are chylomicrons in which most of the triglyceride has been removed so that the size will get smaller but the cholesterol ester is still there. The remaining chylomicrons are carried to the liver and binded to LDL receptor, then enter the lysosomes [24], digestion occurs in lysosomes, fatty acid will solved by cholesterol esters and chylomicron digestive waste product will form deposits in liver cells [25]. Table 11 showed that the difference in the dose of PSP biscuits had a different effect in reducing triglyceride level on hypercholesterolemic rats $(p<0.05)$.

\subsection{HDL (High Density Lipoprotein) Levels}

Table 12 Increase of HDL level on healthy rats

\begin{tabular}{|c|c|c|c|}
\hline $\begin{array}{c}\text { Treatme } \\
\text { nt }\end{array}$ & $\begin{array}{c}\text { Percentage } \\
\text { increase in } \\
\text { HDL levels }(\%)\end{array}$ & $\begin{array}{c}\text { Mean } \\
\text { rank }\end{array}$ & $\mathrm{p}$ \\
\hline $\mathrm{A}_{1}$ & $10.44 \pm 1.28$ & 4.20 & 0.051 \\
\hline $\mathrm{A}_{2}$ & $13.97 \pm 3.40$ & 9.00 & \\
\hline $\mathrm{A}_{3}$ & $15.41 \pm 1.39$ & 10.80 & \\
\hline
\end{tabular}

0.00 Balue represents of five replicates data \pm standard deviation

Table 12 shows the percentage increase in HDL levels on healthy rats from the highest to lowest were $A_{3}$, $A_{2}$, and $A_{1}$. In group $A_{1}$, the lowest percentage increase in HDL was due to only being given standard feed for 14 days. In group $A_{3}$, the percentage increase in HDL was higher than $A_{2}$, that indicates that the amount consumption of PSP biscuits affected the increase in HDL levels in healthy rats. Table 12 showed that the difference in the dose of PSP biscuit had no effect on healthy rats $(\mathrm{p}>0.05)$.

Table 13 The increase of HDL level on hypercholesterolemic rats

\begin{tabular}{cccc}
\hline Treatment & $\begin{array}{c}\text { Percentage } \\
\text { increase in HDL } \\
\text { levels }(\%)\end{array}$ & Mean rank & $\mathrm{p}$ \\
\hline $\mathrm{A}_{4}$ & $10.74 \pm 2.93$ & 4.60 & 0.007 \\
$\mathrm{~A}_{5}$ & $63.08 \pm 3.43$ & 13.00 & \\
$\mathrm{~A}_{6}$ & $13.25 \pm 3.34$ & 6.40 & \\
\hline
\end{tabular}

Value represents of five replicates data \pm standard deviation

Table 13 shows the percentage increase in HDL levels from the highest to lowest was $\mathrm{A}_{5}, \mathrm{~A}_{6}$, and $\mathrm{A}_{4}$ group. In group $\mathrm{A}_{5}$, a significant increase in HDL level was due to the larger amount of consumption of PSP biscuits. The anthocyanin content in PSP biscuits have a role in the increase of HDL levels.

The mechanism of anthocyanins in increasing HDL levels is by increasing LCAT (Lecithin Cholesterol Acyl Transferase) enzyme which converts free cholesterol in hydrophobic cholesterol esters so that it will bind to lipoprotein core particles to form new HDL. Antioxidants in PSP biscuits could increase APO AI which acts as a precursor for the LCAT enzyme and as a ligand that binds to lipoprotein receptors in HDL tissue. HDL containing APO AI is more protective against atherosclerosis [26].

Group $\mathrm{A}_{6}$, were given gemfibrozil $21.6 \mathrm{mg} / 200$ $\mathrm{g}$ rat body weight showed an increase in HDL levels (13.25\%). Gemfibrozil is able to increase HDL levels by its binding to PPAR $\alpha$ (Peroxisome Proliferator Activated Receptors alpha). PPAR $\alpha$ activation will increase factors that had a role in HDL formation, such as APO AI and APO AII. These two molecules are the main constituents of high density lipoprotein. APO AI is a cofactor of LCAT enzymes that have a role in cholesterol efflux from extrahepatic tissue and goes to the liver for excretion. 


\subsection{LDL Levels}

Table 14 Reduction of LDL levels on healthy rats

\begin{tabular}{cccc}
\hline $\begin{array}{c}\text { Treatm } \\
\text { ent }\end{array}$ & $\begin{array}{c}\text { Percentage } \\
\text { reduction of LDL } \\
\text { levels (\%) }\end{array}$ & $\begin{array}{c}\text { Mean } \\
\text { rank }\end{array}$ & $\mathrm{p}$ \\
\hline $\mathrm{A}_{1}$ & $23.23 \pm 9.93$ & 4.40 & 0.007 \\
$\mathrm{~A}_{2}$ & $30.09 \pm 8.31$ & 6.60 & \\
$\mathrm{~A}_{3}$ & $85.40 \pm 20.05$ & 13.00 & \\
\hline Vale represents of five replicates data \pm standard deviation &
\end{tabular}

Value represents of five replicates data \pm standard deviation

Table 14 shows the significantly $(\mathrm{p}<0.05)$ decrease in LDL levels on healthy rats from the highest to lowest were $A_{3}, A_{2}$, and $A_{1}$. $A_{1}$ was the group of rats which had the slower decrease in LDL level than another group rats, it was due to consuming only basal diet for 14 days. In group $A_{3}$, the effect on decreasing LDL levels was more significant which due to the higher consumption of PSP biscuits than $\mathrm{A}_{2}$. The content of anthocyanins and dietary fiber in PSP biscuits contributed to reduced LDL levels in healthy rats.

Table 15 Reduction of LDL level on hypercholesterolemic rats

\begin{tabular}{cccc}
\hline Treatment & $\begin{array}{c}\text { Percentage } \\
\text { reduction of } \\
\text { LDL levels }(\%)\end{array}$ & Mean rank & $\mathrm{p}$ \\
\hline $\mathrm{A}_{4}$ & $33.55 \pm 4.86$ & 7.40 & 0.004 \\
$\mathrm{~A}_{5}$ & $89.00 \pm 5.95$ & 13.00 & \\
$\mathrm{~A}_{6}$ & $21.75 \pm 9.81$ & 3.60 & \\
\hline \multicolumn{4}{l}{ Value represents of five replicates data \pm standard deviation }
\end{tabular}

Table 15 shows the significant $(p<0.05)$ reduction of LDL levels on hypercholesterolemic rats from the highest to lowest was $\mathrm{A}_{5}, \mathrm{~A}_{4}$, and $\mathrm{A}_{6}$. In group $\mathrm{A}_{5}$, the effect on lowering LDL level was higher than group $\mathrm{A}_{4}$, this was due to larger amounts of PSP biscuits consumption, the content in PSP biscuits that was able to reduce LDL levels was anthocyanins and dietary fiber.

The anthocyanins will activate AMPK (Adenosine Monophosphate Protein Kinase) which inhibits ACC (Acetyl-CoA Carboxylase) causing a decrease in fatty synthesis and also lowering the esterification of cholesterol. Fatty acids are basic components of LDL formation [27]. Dietary fiber also affects the disposal of LDL, dietary fiber will bind bile acids and inhibit enterohepatic circulation of bile acids which causes decrease in LDL levels, through the disposal of LDL through feces.

In group $\mathrm{A}_{6}$, were treated with gemfibrozil 21.6 $\mathrm{mg} / 200 \mathrm{~g}$ rat body weight caused a decrease in LDL level by $21.74 \%$. This due to gemfibrozil is able to suppress LDL level in body through its mechanism by binding to PPARa (Peroxisome Proliferator Activated Receptors Alpha) which stimulates the oxidation of Peroxisome beta which metabolizes long chain fatty acids through the activation of Acyl-CoA Oxidase, 2-trans-enoyl Hydratase and thiolase. The end product of metabolism is Acetyl-CoA. Table 13 showed that the difference in the dose of PSP biscuits had a different effect in decrease of LDL levels on hypercholesterolemic rats $(\mathrm{p}<0.05)$.

\subsection{Body Weight}

Table 16 Body weight changes on healthy rats

\begin{tabular}{cccc}
\hline Treatment & $\begin{array}{c}\text { Percentage of } \\
\text { body weight } \\
\text { changes }(\%)\end{array}$ & Mean rank & $\mathrm{p}$ \\
\hline $\mathrm{A}_{1}$ & $7.85 \pm 0.25$ & 13.00 & 0.005 \\
$\mathrm{~A}_{2}$ & $2.90 \pm 0.40$ & 7.00 & \\
$\mathrm{~A}_{3}$ & $2.40 \pm 0.37$ & 4.00 & \\
\hline \multicolumn{7}{l}{ Value represents of five replicates data \pm standard deviation }
\end{tabular}

Table 16 shows the significant $(\mathrm{p}<0.05)$ change in body weight on healthy rats from the highest to lowest was $A_{1}, A_{2}$, and $A_{3}$. In group $A_{1}$, there was a significant increase in body weight. This is due to the provision of standard feed as a daily feed for 14 days. The standard feed had a taste and aroma favoured by rats.

In group $A_{2}$, the increase in body weight was higher than group $\mathrm{A}_{3}$. This is due to dietary content in PSP biscuits that can accelerate the expulsion of food waste through the digestive tract [28]. The level of feed consumption is influenced by the rats according to activity level or movement of the rats [29].

Table 17 Body weight changes on hypercholesterolemic rats

\begin{tabular}{cccc}
\hline Treatment & $\begin{array}{c}\text { Percentage of body } \\
\text { weight changes }(\%)\end{array}$ & $\begin{array}{c}\text { Mean } \\
\text { rank }\end{array}$ & $\mathrm{p}$ \\
\hline $\mathrm{A}_{4}$ & $4.23 \pm 0.40$ & 7.20 & 0.004 \\
$\mathrm{~A}_{5}$ & $5.85 \pm 0.53$ & 13.00 & \\
$\mathrm{~A}_{6}$ & $3.77 \pm 0.42$ & 3.80 & \\
\hline
\end{tabular}

Value represents of five replicates data \pm standard deviation

On hypercholesterolemic rats, the percentage in body weight changes from the highest to lowest was $\mathrm{A}_{5}, \mathrm{~A}_{4}$, and $A_{6}$ (Table 17). The amount of feed consumed affects the amount of energy intake that is stored as fat which will increase the body weight. Excess fat in the form of triglyceride in adipose tissue under the skin and in the abdominal cavity will gain weight, it also will make a low level in leptin sensitivity, causing increased food intake and triggering an increase in body weight [30].

The increase in body weight on group $\mathrm{A}_{4}$ and $\mathrm{A}_{5}$ was caused because PSP biscuits contained complex carbohydrates which were used as the main energy source and also the nutritional content in PSP biscuits were able to improve the body weight [17]. 
In group $\mathrm{A}_{6}$, were given gemfibrozil $\mathrm{mg} / 200 \mathrm{~g}$ rat body weight had a change in body weight but the gain was less than the $\mathrm{A}_{4}$ and $\mathrm{A}_{6}$. This is due to the consumption of gemfibrozil which has side effects on digestion, which causes bloating, nausea and diarrhea. The body weight changes of rats were also caused by several other factors, including: body metabolism, body biological conditions, stress, and differences in treatment.

\section{CONCLUSION}

Based on research, it was found that giving basal diets containing 50\% PSP biscuits for 14 days were able to give a significant hypocholesterolemic effect on both healthy and hypercholesterolemic rats. In total cholesterol levels, the percentage decrease on healthy rats was $30.99 \%$, while on hypercholesterolemic rats was $49.26 \%$. In triglyceride levels, the percentage of decrease was $35.56 \%$ on healthy rats, while on hypercholesterolemic rats was $66.21 \%$. In HDL levels, the increase was $15.41 \%$ on healthy rats, while the hypercholesterolemic rats' increase was $63.08 \%$. In LDL levels, the percentage of reduction was $85.40 \%$ on healthy rats, and on hypercholesterolemic rats was $89.00 \%$. PSP biscuits gave a change in body weight of rats.

\section{REFERENCES}

[1] D. Muchtadi, Laboratory instructions for evaluating the nutritional value of food, Depdikbud PAU Pangan dan Gizi. Institut Pertanian Bogor, Bogor, 1989. [In Bahasa Indonesia]

[2] D.S. Damardjati, Utilization of sweet potatoes in diversification programs to succeed in food selfsufficiency, Balitan, 2005, pp 1-25. [In Bahasa Indonesia]

[3] K. Konoralma, E. V. Rambi, Kawatu, Effectiveness of pedometer use to reduce obesity risk and blood cholesterol level (total, trigliceride, HDL, and LDL) in obesity population at perkamil paal dua of manado city in 2016, Proceeding Manado Health Polytechnic $1^{\text {st }}$ International Conference, 2017, vol. 1, pp. 288-291.

[4] G. Jatnika, S. Hartanto, Efforts in hypercholesterolemia treatment using turmeric (Curcuminoid) extract phytotheraphy on obese patients: preclinical study, Jurnal Keperawatan Padjajaran, 2018, vol. 6. pp. 227-234. DOI: https://doi.org/10.24198/jkp.v6i3.604.

[5] S. Almatsier, Basic principles of nutrition, PT. Gramedia Pustaka Utama, Jakarta, 2009. [In Bahasa Indonesia]
[6] B. S. Jacob, A study on prevalence of dyslipidemia in obese patients in a teaching hospital in kerala, 2015, vol. 2, pp. 642-646.

[7] I. M. Jawi, I. W. P. S. Yasa, A. N. Mahendra, I. W. Sumardika, Effective dose and safety profile of purple sweet potato tablet preparation in rats with high cholesterol diet, Biomedical and Pharmacology Journal, 2020, vol. 13, pp. 665-671. DOI: https://doi.org/10.13005/BPJ/1930.

[8] C. C. Teow, V. D. Truong, R. F. McFeeters, R. L. Thompson, K. V. Pecota, G. C. Yencho, Antioxidant activities, phenolic and $\beta$-carotene contents of sweet potato genotypes with varying flesh colours, Food Chemistry, 2007. DOI:https://doi.org/10.1016/j.foodchem.2006.09.0 33.

[9] I. Khaldun, Erlidawati, Munzir, Stability of natural dyes from purple cassava tubers (Ipomea batatas), Chimica Didactica Acta, 2013, vol. 1, pp. 34-40. [In Bahasa Indonesia]

[10] E. A. Ekoningtyas, Triwiyatini, F. Nisa, The potential chemical content of purple sweet potato (Ipomea batatas L) as an identification material for the presence of plaque on the tooth surface, Jurnal Kesehatan Gigi, 2016, vol. 3(1), pp. 1-6. [In Bahasa Indonesia]

[11] S. Bintanah, E. Handarsari, Fiber intake with blood sugar level, diabetes melitus type 2 at roemani semarang hospital LPPM Unimus, 2012, volume 1, pp.

289-297. jurnal.unimus.ac.id/index.php/psn12012010/article /download/522/571 [In Bahasa Indonesia]

[12] Rosidah, The potential of purple sweet potato as a raw material for the food industry, Jurnal Teknologi, 2014, volume 1(1), pp. 44-52. [In Bahasa Indonesia]

[13] A. Seprina, Study of substitution of wheat flour and cornstarch extract residue (Zea mays L.) in the manufacture of fibrous biscuits, Skripsi, Universitas Lampung, Bandar Lampung, 2010. [In Bahasa Indonesia]

[14] W. T. Friedewald, R. L. Levy, D. S. Fredrickson, Estimation of the concentration of low-density lipoprotein cholesterol in plasma without use of the preparative ultracentrifuge, Clinical Chemical, 1972, vol. 18(6), pp. 499-5-2. DOI: https://doi.org/10.1093/linchem/18.6.499.

[15] R. A. Pamungkas, S. S. Santosa, S. Warsito, Effect. S. S, Effect of ethanol level and quail egg yolk maceration duration total cholesterol HDL and LDL, Jurnal Ilmiah Peternakan, 2013, pp. 1136- 
1142. DOI:. [In Bahasa Indonesia]

[16] R. K. Murray, D. K. Granner, P. A. Mayes, Rodwell, Biochemistry Harper. $25^{\text {th }}$ Edition, Penerbit Buku Kedokteran EGC, Jakarta, 2003. [In Bahasa Indonesia]

[17] Departemen Kesehatan RI, Farmakope Indonesia, Edisi IV, 1995. [In Bahasa Indonesia]

[18] E. D. Sigarlaki, A. Tjiptaningrum, The effect of giving red dragon fruit (Hylocereus polyrhizus) to total cholesterol levels, Jurnal Majority, 2016, volume 5(5), pp. 14-17. [In Bahasa Indonesia]

[19] Kaminsky, Y. G. and E. A. Kosenko. 2010. Molecular mechanism of toxicity of simvastatin, widely used cholesterol-lowering drug. A Review. Central European Journal of Medicine. Volume 5(3), pp. 269-279

[20] A. R. Yuliana, M. Ardiaria, The effect of giving red dragon fruit (Hylocereus polyrhizhus) on triglyceride levels in sprague dawley dyslipidemia rats, Journal of Nutrition College, 2016. DOI: https://doi.org/10.14710/jnc.v5i4.16454. [In Bahasa Indonesia]

[21] N. A. Fithtiani, Effect of onion extract (Allium ascalonicum) on serum triglyceride levels in hyperlipidemic wistar rats, Artikel Hasil Penelitian, 2010. [In Bahasa Indonesia]

[22] B. G. Katzung, Basic and Clinical Pharmacology, Edisi 10, EGC, Jakarta 2012. [In Bahasa Indonesia]

[23] S. G. Ganiswarna, Pharmacology and therapy, Edisi 4, departemen Farmakologi dan Terapeutik FKUI, 1995. [In Bahasa Indonesia]

[24] M. Munawwarah, The addition of muscle strength training in interval training lowers triglycerides for obese students at universitas esa unggul, Jurnal Fisioterapi, 2011, volume 11(1). [In Bahasa Indonesia]

[25] D. Marks, Basic medical biochemistry. A clinical approach, EGC, Jakarta, 2000. [In Bahasa Indonesia]

[26] N. Faadlilah, M. Ardiaria, The effect of infusion of red dragon fruit peel (Hylocereus polyrhizus) on HDL levels of dyslipidemic sprague dawley rats, Journal of Nutrition College, 2016. vol. 5, pp. 280288. DOI: https://doi.org/10.14710/jnc.v5i4.16422. [In Bahasa Indonesia]

[27] Y. P. Hwang, J. H. Choi, E. H. Han, H. G. Kim, J. H. Wee, K. O. Jung, K. H. Jung, K. I. Kwon, T. C. Jeong, Y. C. Chung, H. G. jeong, Purple sweet potato anthocyanins attenuate hepatic lipid accumulation through activating adenosine monophosphate-activated protein kinase in human HepG2 cells and obese mice, Nutrition Research, 2011. DOI: 10.1016/j.nutres.2011.09.026.

[28] M. C. Gulliford, E. J. Bicknell, J. H. Scarpello, Differential effect of protein and fat ingestion on blood glucose responses to high and low-glycemicindex carbohydrates in non insulin-dependent diabetic subjects, American Journal of Clinical Nutrition, $1989 . \quad$ DOI: https://doi.org/10.1093/ajcn/50.4.773.

[29] I. Wahyuningrum, E. Zubaidah, Effect of angkak and addition of rice bran on decreasing of lipid profile of cholesterolemic male wistar rats, Jurnal Pangan dan Agroindustri, 2016, volume 4(1), pp. 127-136. [In Bahasa Indonesia]

[30] D. R. Mayasari, A. Rahayuni, The effect of giving pumpkin seed powder (Cucurbita moschata) to reduce LDL cholesterol in hypercholesterolemic wistar rats, Journal of Nutrition College, 2014, pp. 1-19, DOI: htppa://doi.org/10.14710/jnc.v3i4.6823. [In Bahasa Indonesia] 